Review

\title{
Bone Marrow Gene Therapy for HIV/AIDS
}

\section{Elena Herrera-Carrillo and Ben Berkhout*}

Laboratory of Experimental Virology, Department of Medical Microbiology, Center for Infection and Immunity Amsterdam (CINIMA), Academic Medical Center, University of Amsterdam, Amsterdam 1105 AZ, The Netherlands; E-Mail: e.herreracarrillo@amc.uva.nl

* Author to whom correspondence should be addressed; E-Mail: b.berkhout@ amc.uva.nl; Tel.: +31-20-566-4822; Fax: +31-20-691-6531.

Academic Editor: Eric O. Freed

Received: 11 May 2015 / Accepted: 13 July 2015 / Published: 17 July 2015

\begin{abstract}
Bone marrow gene therapy remains an attractive option for treating chronic immunological diseases, including acquired immunodeficiency syndrome (AIDS) caused by human immunodeficiency virus (HIV). This technology combines the differentiation and expansion capacity of hematopoietic stem cells (HSCs) with long-term expression of therapeutic transgenes using integrating vectors. In this review we summarize the potential of bone marrow gene therapy for the treatment of HIV/AIDS. A broad range of antiviral strategies are discussed, with a particular focus on RNA-based therapies. The idea is to develop a durable gene therapy that lasts the life span of the infected individual, thus contrasting with daily drug regimens to suppress the virus. Different approaches have been proposed to target either the virus or cellular genes encoding co-factors that support virus replication. Some of these therapies have been tested in clinical trials, providing proof of principle that gene therapy is a safe option for treating HIV/AIDS. In this review several topics are discussed, ranging from the selection of the antiviral molecule and the viral target to the optimal vector system for gene delivery and the setup of appropriate preclinical test systems. The molecular mechanisms used to formulate a cure for HIV infection are described, including the latest antiviral strategies and their therapeutic applications. Finally, a potent combination of anti-HIV genes based on our own research program is described.
\end{abstract}

Keywords: bone marrow; hematopoietic stem cell (HSC); virus; antiviral; gene therapy; lentiviral vector; HIV-1; RNAi 


\section{Introduction}

The HIV epidemic, first recognized in 1981, remains one of the major threats to human health. Globally, approximately 35 million people are living with HIV and more than 25 million people have died of HIV-related causes [1]. Finding a safe, effective, and durable HIV vaccine remains a top priority, but despite more than 30 years of research there is still no vaccine that provides effective protection against HIV infection [2,3]. Combination antiretroviral therapy (cART) can significantly prolong the life of HIV-infected individuals. Some studies found no evidence for HIV-1 evolution in patients on suppressive cART [4], but other reports suggested that cART does not fully suppress viral replication and does not eliminate the viral reservoirs [5,6]. Moreover, the toxicity associated with the life-long adherence to cART, together with the appearance of drug-resistant HIV variants in some patients, supports the continuous search for novel drug and original approaches to fight HIV [7]. Gene therapy has emerged as a promising approach for the treatment of HIV/AIDS as it may facilitate the sustained inhibition of HIV replication after a single therapeutic intervention. A single proof of concept was provided by the so-called "Berlin patient," who remained free of detectable HIV after receiving a bone marrow transplant from a CCR5- $\Delta 32$ homozygous donor [8,9]. This genetic defect could be mimicked in a gene therapy setting.

HIV mainly targets CD4 ${ }^{+}$T cells by binding to the CD4 molecule as well as a chemokine co-receptor, usually CCR5 or CXCR4, on the cell surface. In addition macrophages, monocytes, and dendritic cells can be infected by HIV. In theory, both peripheral blood T cells and HSCs from the bone marrow can be selected as the target cells for an anti-HIV gene therapy (Figure 1). However, because T cells have a limited life span and because HIV also infects other cell types of the hematopoietic lineage, it is thought to be a significant advantage to transduce the HSC precursors. The most important characteristics of HSC are their capacity for self-renewal and their ability to restore all blood cell lineages after bone marrow ablation. HSC will differentiate into diverse hematopoietic lineages, supplying the immune system with HIV-resistant cell types that subsequently colonize the blood and tissues. The classic source of HSCs is bone marrow. For more than 45 years, physicians punctured the marrow and drew out the bone marrow cells with a syringe. In the early 1990s, the human umbilical cord and placenta were recognized as a rich source of HSCs. On the other hand, it was known for decades that a small number of HSCs circulate in blood ( 1 log less than their counterpart in the marrow). In the past 10 years, researchers have developed a safe way to efficiently mobilize HSCs from the marrow to the blood by pre-treating the donor with granulocyte-colony stimulating factor (G-CSF). There are no indications of qualitative differences in the differentiated cells derived from peripheral blood, cord blood, and bone marrow. Therefore, the most common method for HSC isolation nowadays is apheresis of peripheral blood because the harvest of cells is easier, with minimal discomfort for the donor, e.g., no requirement for anesthesia and a hospital stay. In this review we discuss the biological perspective for transducing HSCs with an anti-HIV gene and the many options available for choosing the therapeutic gene. We also discuss the gene transfer vector of choice and its design. Finally, we propose a combination of anti-HIV genes to increase the genetic threshold for viral escape based on our own research line. 


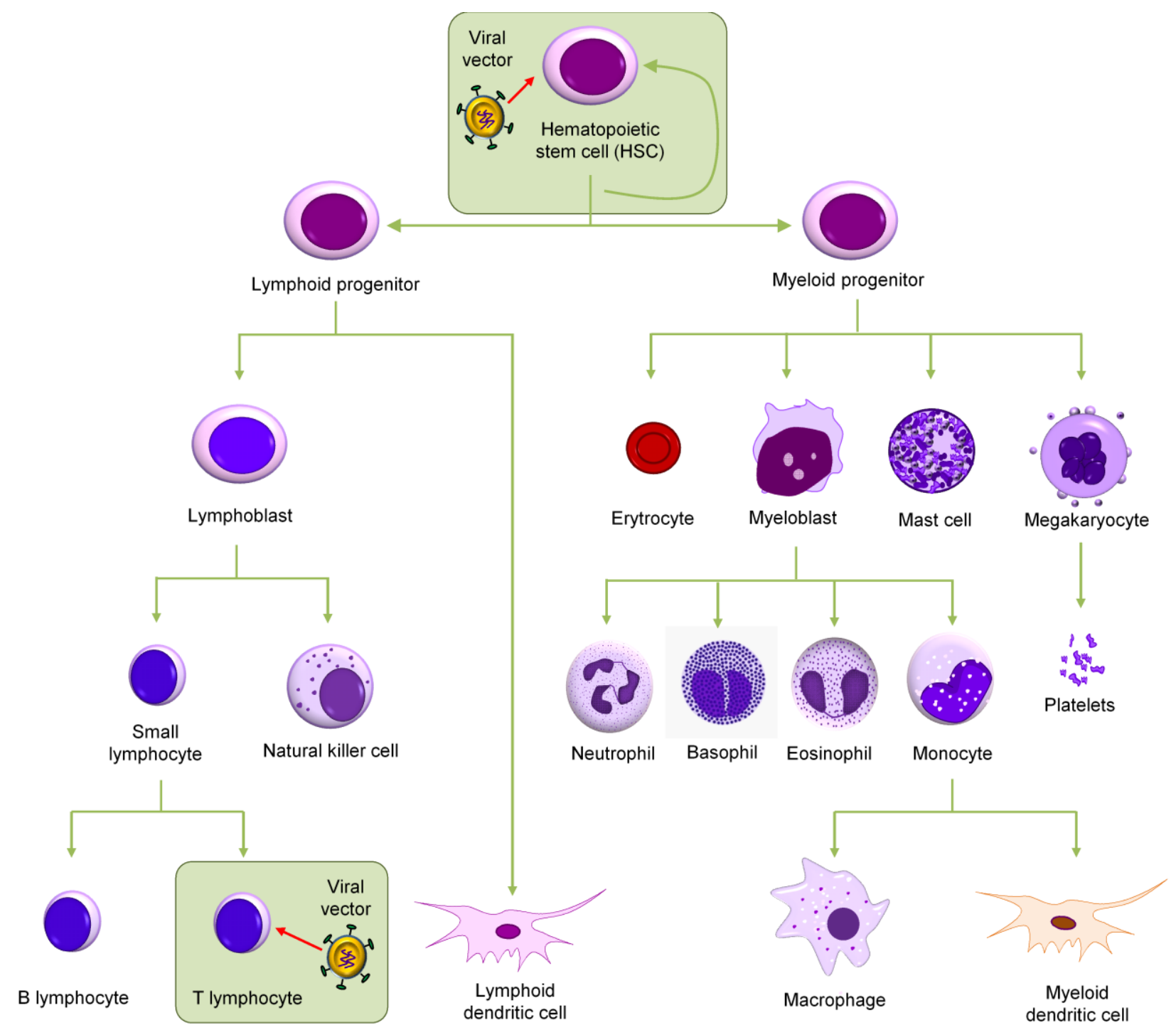

Figure 1. Target cells for an anti-HIV gene therapy. Shown is the scheme of hematopoiesis. Either hematopoietic stem cells (HSCs) from bone marrow or the mature CD4 ${ }^{+} \mathrm{T}$ cells can be targeted. These two cell populations are boxed.

\section{Selection of Therapeutic Targets}

Two gene-based approaches for immune reconstitution of HIV-infected individuals have been developed to date. One approach is based on "artificial T cell receptors." Although patients naturally develop $\mathrm{CD}^{+} \mathrm{T}$ cell responses (cytotoxic T lymphocyte) during the acute phase of HIV-1 infection, this does not suffice for blocking virus replication and does not result in clearance of the virus. The establishment of a latent HIV-1 reservoir forms a major obstacle to viral clearance in the chronic phase of infection. A strategy to clear virus from the body may be to enhance the recognition of HIV-1 infected cells by engineering $\mathrm{T}$ cells. The second approach is based on "intracellular immunization" that aims to protect cells from infection based on the intracellular expression of antiviral genes [10]. The gene products used to combat HIV infection can be classified into two groups: protein and RNA-based inhibitors. We will first discuss $\mathrm{T}$ cell engineering. 


\subsection{Artificial T Cell Receptors}

Initial studies performed in the early 1990s described the potential for enhancing the recognition of HIV-1 infected cells by expressing a molecularly cloned T cell receptor (TCR) specific to HIV proteins, termed artificial TCR. Preclinical in vivo studies demonstrated suppression of HIV in humanized mice that were injected with $\mathrm{T}$ cells expressing the artificial Gag-SL9 TCR [11]. However, effective HIV-specific cytotoxic T lymphocytes are restricted by HLA class I alleles and therefore cannot be applied universally. To avoid HLA restriction of artificial TCRs, T cells can be engineered to express a chimeric antigen receptor (CAR), which combines the specificity of an antibody and the intracellular signaling capacity of a $\mathrm{T}$ cell receptor. Preclinical studies of $\mathrm{CD}^{+} \mathrm{T}$ cells engineered to express CAR have demonstrated antigen-specific proliferation, inhibition of HIV replication, and cytolytic activity against HIV-infected T cells [12,13]. A recent study based on the results of three clinical trials (clinical trial NCT01013415 and [12,14]) indicated that CAR gene therapy is safe [15]. However, the level of CAR-modified cells was found to decrease over time, thus limiting the durability of the anti-HIV effect [12], but other studies reported a remarkable persistence of CAR-modified cells [14-16]. Engineering of HSCs to express CAR molecules may allow for the prolonged production of long-lived non-susceptible cells and eliminate the risk of generating self-reactive hybrid TCR pairs because modified cells would be naturally selected in the thymus [17].

\subsection{Intracellular Immunization}

Over the last two decades several anti-HIV gene therapy approaches have been developed. The anti-HIV gene products will interfere with crucial steps of the viral replication cycle or target a cellular factor that is required for virus replication. Figure 2 illustrates the steps of HIV-1 replication cycle that can be targeted. The viral replication cycle is arbitrarily divided into two stages: the early stage refers to the steps of infection from cell binding to the integration of the viral DNA into the cell genome, whereas the late stage begins with viral gene expression from the integrated provirus and leads to the release of the immature virions that subsequently mature into infectious particles (for further details, see the Figure legend). Initially, anti-HIV genes were designed to inhibit HIV transcription or translation, which occur during the late stage of the replication cycle. More recently, laboratories have developed anti-HIV therapies based on the inhibition of early replication stage, which may be beneficial for a robust antiviral effect. According to the gene products used to combat HIV infection, the gene therapy strategies are classified into two groups: protein and RNA-based therapies. 


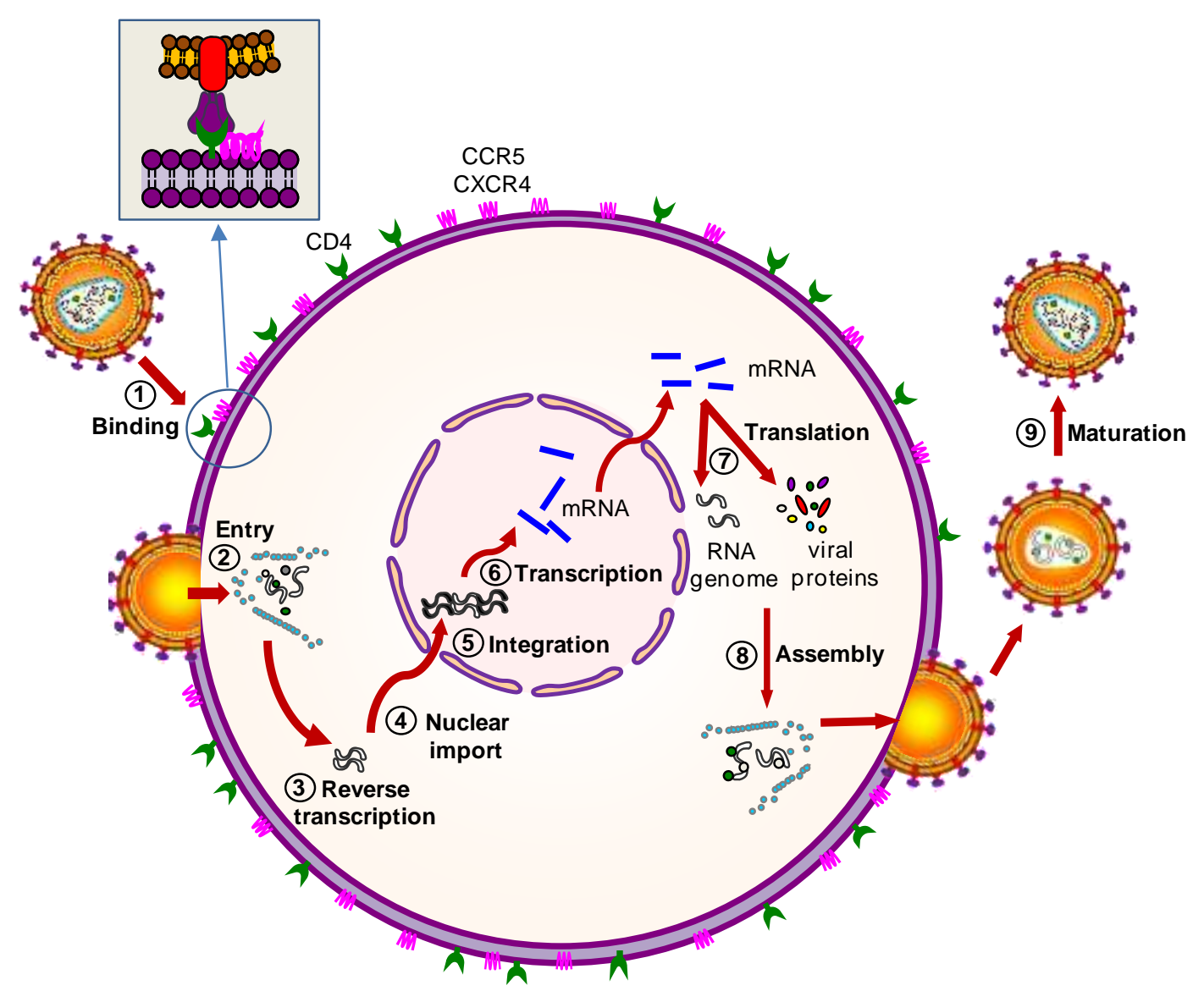

Figure 2. Steps of the HIV-1 replication cycle that can be targeted by gene therapy. The HIV-1 replication steps that can be targeted by gene therapy are shown: (1) HIV-1 binding to cell membrane; (2) HIV-1 entry into the cell; (3) reverse transcription; (4) transport of the HIV-1 proviral genome into the nucleus; (5) integration of the viral genome into the cellular DNA; (6) transcription of the HIV-1 proviral genome; (7) translation of the viral messenger RNA (mRNA) into new viral proteins; (8) virion assembly inside the cell; and (9) maturation of the immature virion into a completely infectious particle.

\subsubsection{Protein-Based Therapies}

Proteins can be engineered to inhibit either viral or cellular targets. Protein-based strategies include trans-dominant negative proteins (an altered form of a viral or cellular protein that can inhibit the normal function of its wild-type counterpart), fusion inhibitors (a protein or peptide that affects the fusion process during viral entry into the cell), intrabodies (recombinant antibodies expressed intracellularly), intrakines (modified intracellular chemokines), host restriction factors, and nucleases. The first protein tested in a HIV gene therapy trial was an altered form of the HIV Rev protein termed RevM10. RevM10 is a trans-dominant Rev mutant that interferes with the normal Rev function and thereby prevents the export of unspliced genomic HIV RNA from the nucleus to the cytoplasm [18-20]. Cells expressing RevM10 were shown to have a survival advantage in HIV-infected individuals, but no substantial impact on the viral load was observed [21,22]. Other trans-dominant negative HIV-1 proteins have been developed, including Tat mutants that prevent transactivation of the viral LTR promoter [23] and Vif- and 
Gag-based trans-dominant inhibitors [24-27]. Mutants of cellular proteins that act as co-factors of virus replication have also been evaluated as trans-dominant negative molecules (e.g., S6 [28], Sam68 [29,30], or HDAC1 [31]).

A different protein-based approach is based on secreted antiviral proteins. Several laboratories have genetically engineered truncated and soluble forms of CD4 (sCD4) that exhibit antiviral properties [32-34]. However, the secretion level of sCD4 was too low to efficiently inhibit HIV. Recently, promising results were obtained with a fusion inhibitor based on a 46 amino acid domain of the HIV-1 Envelope gp41 protein (C46) that prevents membrane fusion [35]. The C46 peptide has also been stably expressed as a membrane-anchored peptide (maC46) that was able to inhibit replication of a broad range of HIV-1 isolates [36,37]. The safety of maC46 has been confirmed in a phase I clinical trial in which autologous T cells, transduced with a retroviral vector expressing maC46, were infused into patients [38]. However, the in vivo antiviral effect remains currently unknown. Secreted neutralizing antibodies or intrabodies have been developed against the viral Tat, Vif, Reverse Transcriptase, and Integrase proteins and have been shown to inhibit virus replication in gene-modified cells in vitro [39-44]. However, the neutralization breadth of these intrabodies was limited. For instance, although the anti-Tat intrabody was expected to increase the relative survival of transduced cells in vivo by blocking the Tat-TAR axis that controls viral gene expression, the number of transduced cell level progressively decreased and was too low to cause a therapeutic effect [44]. In another attempt to inhibit HIV entry, several modified intracellular chemokines or intrakines were designed to block the surface expression of HIV-1 CCR5 co-receptor, but modified cells retained a residual co-receptor level on the cell membrane that suffices for HIV-1 entry [45-47].

An alternative strategy to block the expression of HIV-1 co-receptors is to engineer nucleases that are specific for sequence motifs in the co-receptor genes. Various approaches have been explored to enable selective gene editing: zinc finger nucleases (ZFNs), transcription activator-like effector nucleases (TALENs), and, most recently, CRISP/Cas9 nucleases. Most studies have focused on the genes encoding the HIV-1 co-receptor CCR5 and CXCR4, but the integrated HIV-1 DNA genome can also be targeted [48-56]. The major hurdle with genome-editing systems concerns the possible off-target effects that may lead to non-specific genome modifications. This issue must be solved before genome editing can be considered for anti-HIV-1 gene therapy. Recently, several groups demonstrated that antiviral restriction factors can also be exploited for anti-HIV gene therapy applications [57]. For instance, the human TRIMcyp protein was shown to potently inhibit HIV in human T cells and macrophages in vitro and in vivo [58]. Nevertheless, the introduction or overexpression of exogenous restriction factors may induce an unwanted immune response that eventually results in the removal of the modified cells. Thus, the feasibility of this approach needs to be addressed in larger clinical trials.

We also would like to mention some exciting recent studies on gene therapy vectors that should provide protection against HIV-1 transmission. This novel strategy is called Vectored Immuno Prophylaxis or VIP and is based on the production of an anti-HIV transgene-encoded antibody. VIP yields immunological protection (like a vaccine), but without actively invoking the immune system (antigen design, production and vaccination) [59-61]. In particular, VIP yielded sustained expression of multiple antibodies at a high level upon a single intramuscular injection in mice [62]. These antibodies confer anti-HIV activity and protected humanized mice against an HIV-1 challenge [62,63]. 


\subsubsection{RNA-Based Therapies}

Similar to anti-HIV proteins, RNAs can be designed to target either viral or cellular products. RNA molecules have an advantage over proteins because nucleic acids are not immunogenic and RNA-based therapies may therefore be more suitable for long-term applications. In addition, RNA-based therapies mostly work in a sequence-specific manner, thus avoiding adverse effects in the cell. Although cellular targets are less prone to mutations that may trigger viral escape, there may be serious side effects of downregulating cellular products. Therefore, HIV-1 products have been the preferred target for antiviral RNAs. RNA-based strategies include antisense, ribozymes, aptamers, small interfering RNAs (siRNAs), short hairpin RNAs (shRNAs), and the related AgoshRNA design that was recently discovered. The agents that act through the RNA interference (RNAi) mechanism: siRNA, shRNA, and AgoshRNA will be explained in more detail because they form a more recent addition to the antiviral arsenal.

To date numerous antisense RNA molecules have been designed to target HIV-1 mRNAs in a sequence-specific manner, resulting in the formation of non-functional RNA duplexes that are subsequently destroyed. Antisense RNA molecules against the HIV-1 trans-activation response element (TAR) and Envelope-encoding sequences of HIV-1 RNA have been designed and shown to inhibit HIV in vitro [64-66]. Ribozymes are similar to antisense RNA molecules but have an added catalytic activity. Ribozymes have been directed against tat/vpr [67-69], rev/tat [70], and U5 leader sequences [71] of the HIV-1 RNA genome and have shown promising antiviral activity in vitro [72,73]. However, the ribozyme-only treatments have not demonstrated a therapeutic effect in clinical trials [69]. RNA aptamers do not attack the HIV RNA genome. Instead, these oligonucleotides competitively bind and sequester specific molecular targets, thus inhibiting their biological function. Anti-HIV-1 aptamers are mainly based on TAR and Rev-responsive elements (RRE), thus neutralizing the action of the HIV-1 proteins Tat and Rev, respectively. The inhibitory effect of TAR and RRE aptamers was reported in vitro [74-77] and in vivo [78,79], but no antiviral effect was observed in the only clinical trial to date that exclusively used aptamers [80].

More recently, RNAi has evolved as a powerful tool to regulate gene expression post-transcriptionally in a sequence-specific manner. The RNAi mechanism uses double-stranded RNA molecules (dsRNA) to trigger mRNA degradation (Figure 3). First, a primary miRNA transcript (pri-miRNA) is made, of which a hairpin-like RNA structure is processed by the "Microprocessor" complex, which consists of the Drosha nuclease and its dsRNA-binding partner DGCR8. The resulting pre-miRNA is cleaved near the terminal loop by the Dicer nuclease in collaboration with the trans-activation response RNA-binding protein (TRBP) and protein activator of PKR (PACT) cofactors [81]. This miRNA pathway yields the mature RNA duplex, of which one strand of approximately 22 nucleotides is preferentially loaded into the Argonaute (Ago) enzyme as part of the RNA-induced silencing complex (RISC). The miRNA-loaded RISC complex targets a partially complementary mRNA transcript for degradation and/or translational repression. This mechanism is conserved in all eukaryotes and can be exploited for therapeutic gene silencing. The canonical RNAi pathway can be triggered by artificial substrates as synthetic siRNAs that can be transfected into the cells (Figure 3, right, canonical pathway) [82]. Antiviral activity of siRNA molecules targeting the HIV RNA genome (Nef, Tat, Gag, Vif, Env) or the mRNA for important cellular co-factors has been reported in short-term virus replication experiments [83-88]. However, 
HIV-1 causes a chronic infection and infected patients require long-term treatment, which cannot easily be accomplished for synthetic siRNAs, in part due to inefficient delivery of nucleic acids into cells.

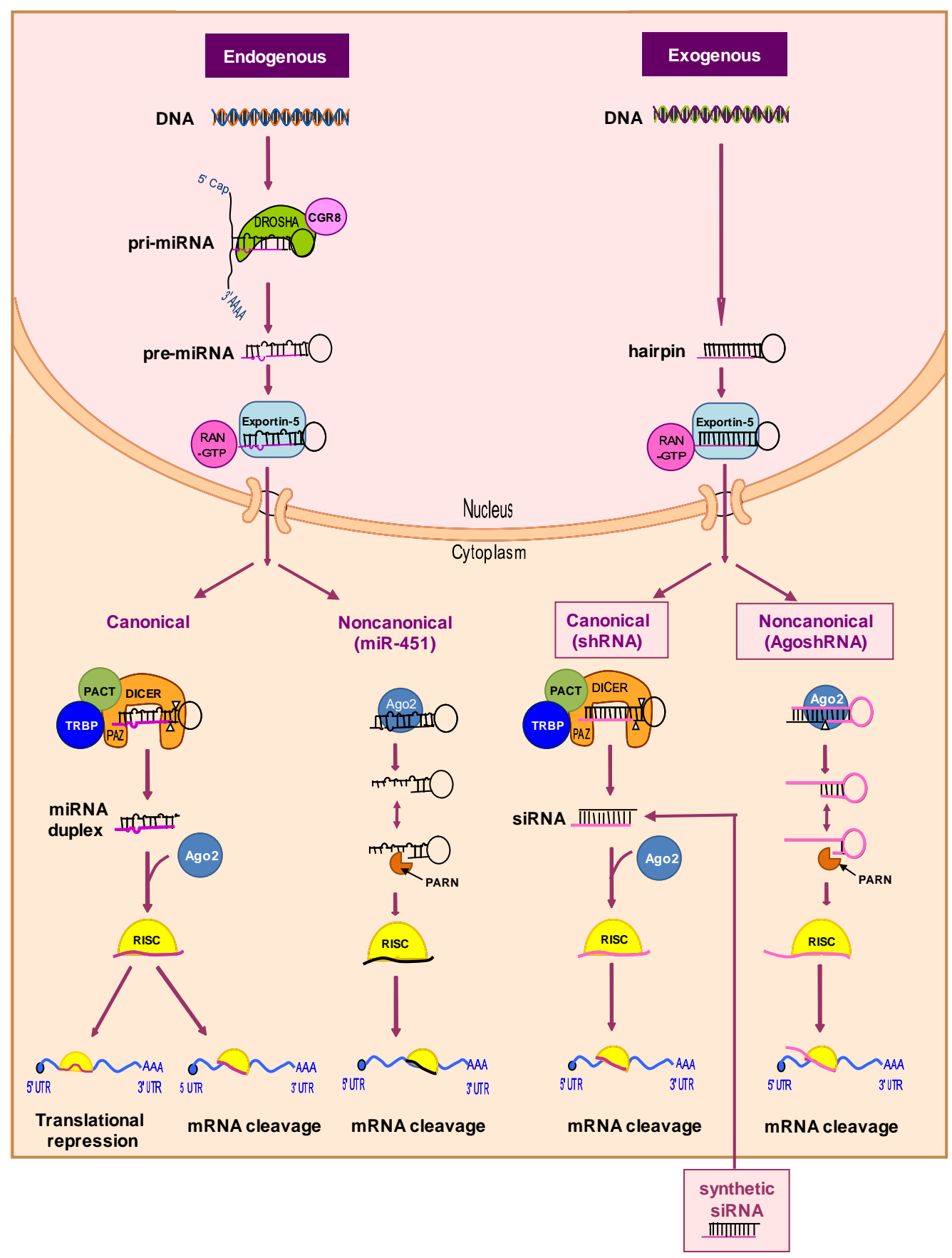

Figure 3. The endogenous miRNA and exogenous shRNA processing pathways. The intracellular processing pathways are depicted starting from the miRNA gene of the cell (endogenous) or the transduced shRNA gene cassette (exogenous). The canonical Dicer-dependent and noncanonical Dicer-independent pathways are depicted for both molecules. Ago2 plays an essential role in Dicer-independent pathways. See the text for further details. PACT: Protein activator of protein kinase R; Pri-miRNA: Primary miRNA; Ago2: Argonaute 2 nuclease; RISC: RNA-induced silencing complex; TRBP: Transactivation response RNA-binding protein. 
An alternative to the regular injection of exogenous siRNA is the expression of shRNAs from a transgene construct in the target cells [89,90]. The shRNA is synthesized in the nucleus, transported to the cytoplasm by the Exportin-5 protein, and processed by the Dicer endonuclease into siRNAs of $\sim 21$ bp with 2-nt 3' overhangs (Figure 3, right, canonical pathway) [91]. The "passenger" strand of the siRNA is degraded and the "guide" strand programs RISC to cleave the perfectly complementary target mRNA. Recent evidence indicates that one can also design Dicer-independent shRNAs [92]. We recently identified a specific shRNA design with a short stem and small loop that triggers this alternative processing route $[93,94]$. This special shRNA design was named AgoshRNA to reflect the dual role of Ago 2 in processing and subsequently target RNA cleavage. The AgoshRNA design possess several potential advantages over regular shRNAs, but more studies are required to demonstrate their knockdown efficacy [93].

AgoshRNAs may become the silencing method of choice in diverse situations, e.g., in cells such as monocytes that lack a significant amount of Dicer [95]. In addition, saturation of Dicer as a critical component of the cellular RNAi pathway may not occur with AgoshRNAs. Moreover, only a single RNAi-active guide strand is produced, which is an important feature to restrict RNAi-induced off-target effects due to the passenger strand. Ago2-mediated processing of shRNAs also yields more precise ends compared to Dicer processing, which is notoriously inaccurate [96,97]. Finally, AgoshRNAs may mimic the Dicer-independent cellular miR-451 that is loaded exclusively into Ago2, thus avoiding off-target effects via Ago1, 3, and 4 [98]. However, it remains to be seen whether the regular shRNA or novel AgoshRNA design yields more effective molecules and we think that the latter design can still be improved [99,100].

\section{Combinatorial Approaches}

HIV mutates rapidly due to the high viral turn-over in patients and the significant mutation frequency of the HIV-1 Reverse Transcriptase enzyme, which lacks a proofreading mechanism. Thus targeting of a host cell co-factor may represent a less escape-prone antiviral option. However, host targeting may cause cytotoxicity and viral escape would be possible through adaptation to an alternative cellular co-factor. Like the use of a single antiviral drug, gene therapy with a single anti-HIV gene is prone to virus escape. Therefore, effective gene therapy applications against HIV will likely require a combination of anti-HIV genes targeting different HIV-1 components or important co-factors [90,101,102]. Besides additive inhibition, this combinatorial approach will raise the genetic threshold for the evolution of drug-resistant virus variants as multiple mutational hits will be required in multiple target sites. Accordingly, several groups have incorporated multiple anti-HIV genes into a single vector.

Our group has investigated different combinatorial RNAi approaches (Figure 4). For instance, multiple shRNA cassettes can be combined in the same vector [103]. Different promoters were used to express three shRNAs against HIV-1 to avoid recombination-mediated deletion of shRNA cassettes on repeated promoter sequences. Multiple inhibitors can also be generated from a polycistronic miRNA transcript $[104,105]$. A recent study showed that multiple shRNAs can be effectively expressed from a single vector via tandem repeats of different miRNA-based backbones [106]. This strategy is called multiplexed miRNA-based shRNAs (shRNA-miRs). When peripheral blood mononuclear cells from HIV-1 seropositive individuals were transduced with a shRNA-miRs vector and transplanted into 
mice, efficient suppression of virus replication and restoration of the CD4 T cell count was observed. Alternatively, extended shRNAs (e-shRNA) expressing two or three siRNAs or long hairpin RNAs (lhRNA) encoding many siRNAs can be designed [107-110]. However, most silencing activity is lost for the extended RNA duplex designs. Figure 4 lists the major advantages and disadvantages of the different combinatorial RNAi strategies [111].

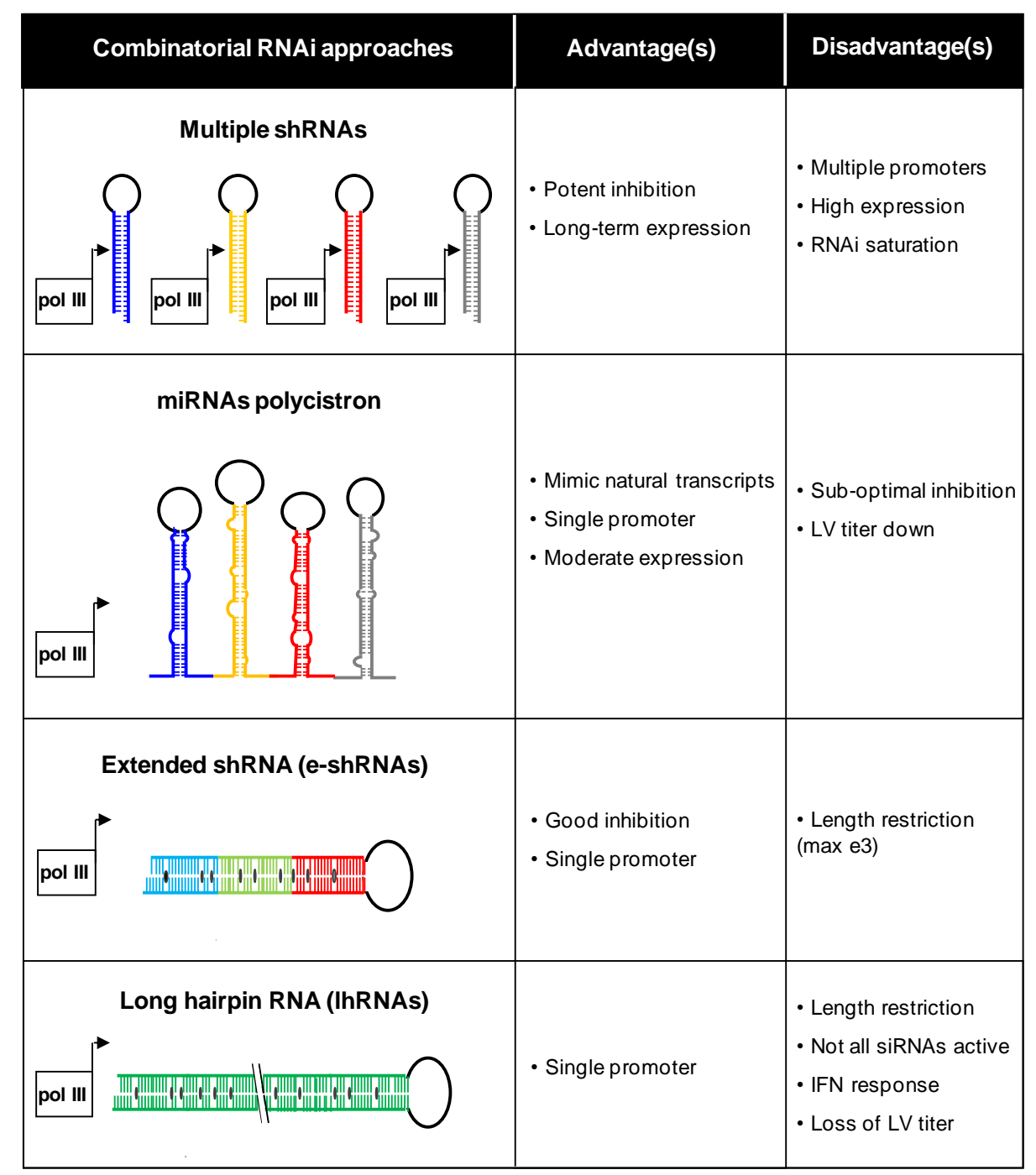

Figure 4. Combinatorial RNAi strategies. Four inhibitory scenarios are plotted with the respective advantages and disadvantages. This figure was adapted from [111]. LV: lentiviral vector.

The RNAi inhibitors can be combined with other protein and RNA-based inhibitors [102] or conventional antiretroviral drugs [112,113]. For instance, one study employed a combination of CCR5 shRNA, chimeric human/rhesus TRIM5a, and a TAR aptamer and a different study employed a TAR aptamer, CCR5 ribozyme, and a tat-rev shRNA [114,115]. These studies demonstrated no apparent toxicity for the combination of antiviral genes. In a separate study, a combination of the membrane-anchored peptide (maC46) and multiple tat/rev shRNAs were combined in a single vector [116]. Our group demonstrated that "second-generation" shRNAs can also be combined with protease inhibitors to avoid the evolution of clinically relevant drug-resistance mutations in 
the protease-encoding gene [113]. One could even create hybrid molecules that combine siRNA and other antiviral activities, e.g., an RNA aptamer that binds to and neutralizes the viral Envelope protein $[117,118]$. Although these results are promising, the key question is whether these compounds can effectively block viral escape.

\section{Vector Choice}

To fight chronic diseases like HIV infection, stable transduction of target cells with the transgene is desirable to avoid repeated administration of anti-HIV molecules. To achieve a durable therapeutic effect, viral vectors that integrate into the host genomes seem the preferred route. Mostly vectors derived from gamma-retroviruses (murine leukemia virus) and lentiviruses (HIV-1) have been used in clinical trials to treat HIV-1 infection [38,102]. The viral genome has been truncated and modified in a number of ways to generate vectors that are safe for clinical use. Both gamma-retroviral and lentiviral vectors (LV) integrate randomly into the host cell genome [119]. As a consequence, integration of the vector may cause insertional oncogenesis. Gamma-retroviruses usually integrate near transcriptional start sites, and severe side effects and the induction of leukemia have been reported in clinical trials [120]. LVs tend to integrate within introns of transcribed regions, thereby limiting their potential to cause insertional oncogenesis [121]. Nevertheless, one should remain careful because some clonal expansion of HIV-infected cells has been observed in infected patients [122,123]. Nevertheless, the development of leukemia due to an HIV-1 integrating event has never been observed in HIV-1 infected individuals. An additional advantage of the LV design is that this vector can infect dividing cells as well as non-dividing cells and terminally differentiated cells, while the gamma-retroviral vector can only infect dividing cells. Given the lower risk of insertional oncogenesis and the ability to effectively transduce many cell types, including HSC, we have chosen the LV system for delivery of the antiviral payload.

The first demonstration of HSC transduction with a LV was presented in 1996 and since then this vector has been extensively modified to increase the efficiency and safety [124]. The HIV genome encodes nine genes, of which four are dispensable for in vitro virus propagation [125]. Therefore, these four accessory genes were deleted, together with the wild-type envelope gene (Figure 5A). An envelope protein of a different virus is included instead, most often the glycoprotein of vesicular stomatitis virus (VSV) due to its broad target cell tropism [124]. In addition, Gag-Pol (SYNGP), Rev (RSV-rev), and VSV-g genes are separated on plasmids and expressed from a heterologous promoter, while the region in the viral vector between the Long Terminal Repeats (LTRs) is replaced with the therapeutic gene on a fourth plasmid to minimize the risk of generating a replication-competent virus through recombination. Further improvement of the biosafety was achieved by construction of self-inactivating (SIN) vectors. SIN vectors contain a deletion in the U3 region of the $3^{\prime}$ LTR that is transferred to the $5^{\prime}$ LTR promoter during reverse transcription, leading to transcriptional inactivation of the vector in transduced cells $[126,127]$. This self-inactivating vector design diminishes the risk of oncogene activation by promoter insertion and reduces the risk of vector mobilization and recombination with the wild-type virus [128]. 
A

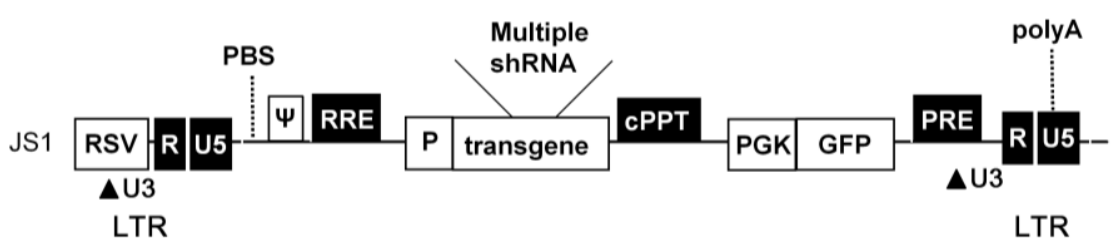

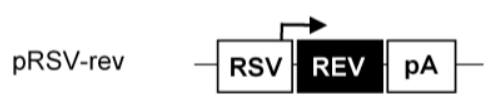

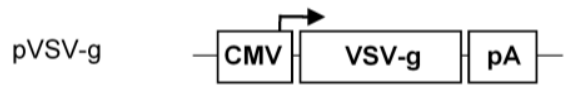

pSYNGP \begin{tabular}{rl|l|l|}
$\longrightarrow$ & \multicolumn{1}{c}{ CMV } \\
\hline
\end{tabular}

B

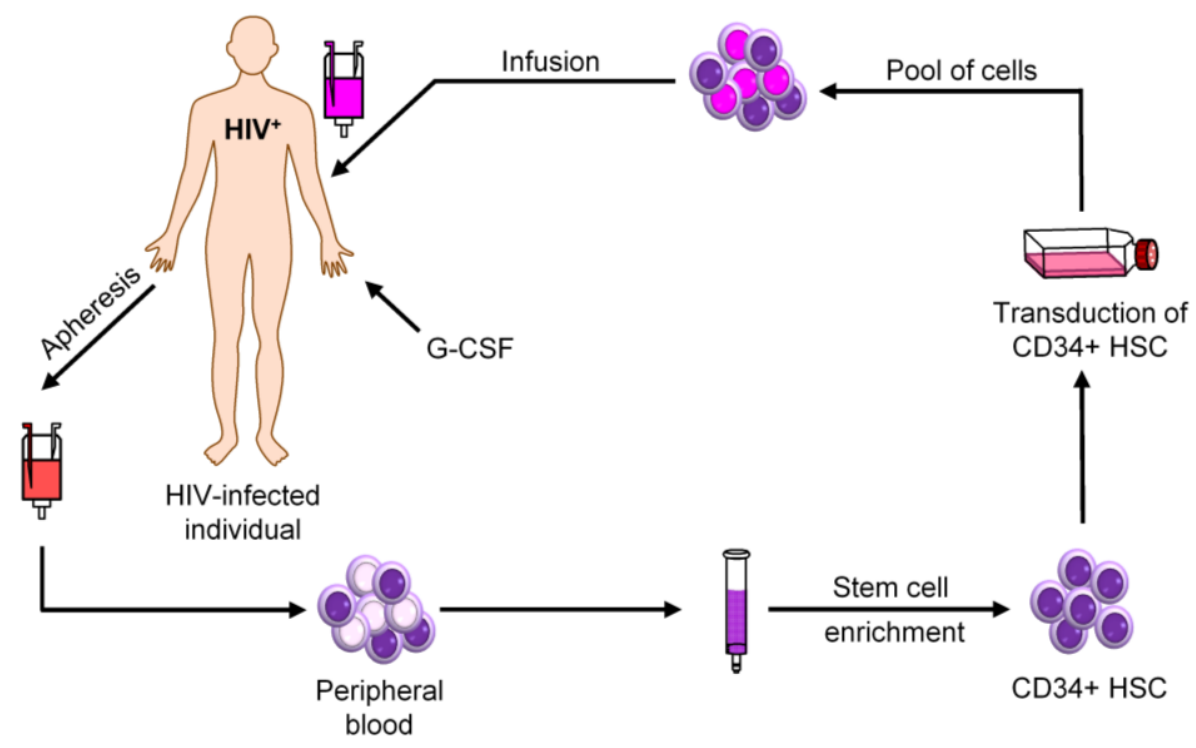

Figure 5. Self-inactivating lentiviral vectors for stable shRNA expression. (A) The lentiviral vector JS1 is shown with three plasmids needed for lentiviral vector production. The vector genome is expressed from the Rous Sarcoma Virus (RSV) promoter. Transcripts start with the HIV-1 R and U5 regions and the packaging signal $(\psi)$. The enhanced green fluorescent protein (GFP) reporter is expressed from the phosphoglycerate kinase promoter (PGK). Transcription of the vector genome and the GFP reporter terminates at the HIV-1 polyA signal within the 3' LTR; (B) Scheme of a hematopoietic stem cell (HSC) clinical trial. An HIV-infected patient who fails on regular drug therapy will undergo apheresis for the collection of $\mathrm{CD}_{3} 4^{+} \mathrm{HSC}$ after pretreatment with granulocyte-colony stimulatory factor (G-CSF). The mixed cell population containing CD34+ ${ }^{+} \mathrm{HSC}$ will be purified and transduced ex vivo with the therapeutic construct. Transduced cells will be infused back into the patient and the antiviral gene should protect these cells against HIV-1.

Another biosafety-related issue is the administration of a minimal amount of viral particles to prevent side effects. To allow the use of a minimal dose of viral particles for cellular transduction, the third generation LV has an optimized transduction efficiency using a central polypurine tract (cPPT) sequence 
and a post-transcriptional regulatory element (PRE) from the woodchuck hepatitis virus. For the development of a clinical gene therapy application, it is essential that the vector can be produced to high titers and that the vector is genetically stable. $\mathrm{LV}$ is efficient in transducing $\mathrm{CD} 4^{+} \mathrm{T}$ cells and HSCs. However, the LV system is based on HIV-1, which may complicate its use as a vehicle to deliver anti-HIV-1 genes, e.g., RNAi inducers. We previously discussed these potential problems and presented protocols to effectively use LV for an RNAi-based attack on HIV-1 [129-131]. Briefly, it is important to avoid targeting of HIV-1 sequences that are also present in the LV system. This requirement can frequently be met by using codon-optimized versions of the gag/pol and rev vectors that were generated to improve safety (marked in black in Figure 5A). Another potential issue is that the anti-HIV gene may target sequences in the LV, thus reducing the production or titer by "self-targeting." This problem can be avoided by careful selection of shRNAs that do not target parts of the LV backbone.

To date, the LV system has been shown to be effective for in vitro delivery, integration, and stable expression of transgenes in the hematopoietic system. For a durable HIV-1 treatment, one can transduce HSC ex vivo with a LV encoding different HIV specific inhibitors (Figure 5B). The transduced cells should constitutively express the inhibitors and thus be resistant to HIV-1 infection. The protected HSC are engrafted back into the patient, where they will give rise to an HIV-1 resistant myeloid and lymphoid cell population. This approach would ideally only need a single infusion. Engraftment of autologous transduced HSC will not only result in a steady production of HIV-1 resistant T cells, but also other HIV-1 susceptible cells, e.g., macrophages and monocytes. Gene-modified cells will theoretically have a survival advantage over non-modified cells in HIV-infected individuals as the infected cells will be recognized and destroyed by the patients' immune system. Thus, the autologous transplant should eventually be able to (partially) reconstitute the immune system.

\section{Preclinical Safety and Efficacy Tests}

For a discussion of the required preclinical safety and efficacy tests, we would like to focus on the research line that we have developed since 2004. We proposed an RNAi-based gene therapy for the durable control of HIV-1 infection. We started by screening many shRNA candidates that target important HIV-1 sequences and selected the most potent inhibitors. These shRNAs target highly conserved viral sequences, with $100 \%$ sequence identity among at least $70 \%$ of HIV-1 genomes of all subtypes. We could make a human $\mathrm{T}$ cell line fully resistant to HIV-1 by expression of a single shRNA, but we also described viral escape by the selection of a point mutation in the target sequence [87,90,132,133]. We therefore designed LV that express a combination of four shRNAs (R4A) that target highly conserved sequences in the HIV-1 RNA genome. The safety and efficacy of the combinatorial RNAi-based gene therapy can first be probed in vitro. We tested the four candidate shRNAs in a competitive cell growth (CCG) assay based on the difference in proliferation rate of shRNA-transduced (GFP-positive) and untransduced cells in the same culture. We observed a negative impact of one of the four shRNAs on in vitro cell growth [134]. The safety of this combinatorial RNAi approach should also be tested in appropriate in vivo models to prepare for a clinical trial in humans. In particular, we used the BRG-HIS mouse model in which immunodeficient newborn mice are injected with human hematopoietic progenitor cells. These mice build a fairly complete human immune system consisting of different cell lineages, including mature T cells. This complex process of hematopoiesis can 
be monitored to screen for a negative impact of the HSC gene therapy on cell development. For instance, we tested the impact of LV-transduced anti-HIV shRNAs cells and observed normal development of the human immune system and no adverse effects for three of the four shRNAs tested. The shRNA that showed some adverse effects in vivo also demonstrated a negative effect in the CCG assay, which allowed us to reformulate the shRNA cocktail [135]. The three nontoxic and potent antiviral shRNAs were used to design the combinatorial RNAi vector R3A. Each shRNAs targets a highly conserved sequence of the HIV-1 RNA genome encoding the Integrase, Protease and Tat-Rev proteins [90]. Other therapeutics approaches (e.g., zinc-finger nucleases or ZFN) were also tested in this pre-clinical mouse model [136].

The efficacy of the R3A vector was shown in vitro in experimental settings with pure cultures of modified $T$ cells and subsequently with mixed cultures of modified and unmodified cells [135,137]. It was confirmed that no viral escape occurs with the combinatorial R3A regimen in prolonged mixed cultures, which renders this combination therapy durably effective. It is also important to test the impact of HIV genetic diversity on the combinatorial RNAi regimen proposed. Therefore, the efficacy of R3A was tested against a broad panel of HIV isolates and subtypes. The results demonstrate the broad effectiveness of the triple shRNA regimen [138]. Based on these promising in vitro results, the therapeutic potential of this combinatorial RNAi approach should be tested in appropriate in vivo models. These studies are currently being addressed in the BRG-HIS mouse model.

\section{Clinical Studies}

We consider a lentiviral gene therapy for HIV-infected patients who fail on regular ART, where autologous HSCs will be transduced ex vivo with the LV encoding the triple shRNAs. In theory, the transduced HSCs will durably supply all derived immune cells with the combination of antivirals. Because preferential survival of the shRNA-expressing cells over unprotected cells in the presence of HIV-1 is expected, perhaps a single gene therapy treatment will suffice. Theoretically, unprotected cells will be infected and removed by the immune system. This survival benefit of protected cells should result in a gradual increase in the percentage of cells that are not susceptible to HIV-1 infection, restoration of the damaged immune system, and hopefully a blockage of disease progression towards AIDS. Although the feasibility of such a cell-based gene therapy has recently been demonstrated in a pilot clinical study [139], successful application of modified HSCs for HIV treatment requires further optimization to improve the transduction efficiency and enhance the engraftment of the modified cell population. In this regard, the use of mild myeloablation methods may facilitate more efficient engraftment, an approach that can be used in a safe manner in a gene therapy setting [140,141].

To date, only a few anti-HIV gene therapy protocols have progressed towards clinical trials, mostly addressing the feasibility and safety of gene-transduced autologous HSC transplantation in patients. Table 1 summarizes some of the clinical trials performed with gene-modified HSC to date. We did not list the trials that target mature $\mathrm{T}$ cells. 
Table 1. Clinical trial of HIV gene therapy based on modified HSC transplantation.

\begin{tabular}{ccc}
\hline Gene Therapy Mechanism & Phase & Reference(s) \\
\hline Rev-responsive element decoy (Rev protein) & Pilot & {$[80]$} \\
Trans-dominant Rev (Rev protein) & I-II & {$[142]$} \\
Ribozyme (Tat/Rev mRNA) & II & {$[69,143]$} \\
& & NCT00074997 \\
& & NCT00002221 \\
& II & NCT01177059 \\
& I-II & NCT00003942 \\
Combinatorial trans-dominant Rev (Rev protein) and antisense (Pol mRNA) & I-II & NCT01734850 \\
Combinatorial strategy: fusion inhibitor C46 (Env protein) and shRNA (CCR5) & Pilot & {$[102]$} \\
Combinatorial strategy: shRNA (Tat/Rev mRNA), & & NCT00569985 \\
TAR decoy (Tat protein) and ribozyme (CCR5) & & NCT01153646 \\
\hline
\end{tabular}

\section{Conclusions}

Although current cART can potently reduce the plasma HIV viral load to undetectable levels in most patients, it is not curative. cART remains expensive because of the need for life-long drug adherence. Other cART problems are the side effects observed in some patients after long-term drug intake and the possibility that drug-resistant virus variants evolve. Although HSC gene therapy will also be expensive, it presents an attractive alternative that has the potential to control HIV infection with a single treatment. Genetically modified HSCs and all derived cell types will continuously produce the anti-HIV genes. Anti-HIV genes can be designed to interfere with crucial steps of the viral replication cycle either by targeting a viral factor or a cellular factor required for virus replication. For the success of a HSC gene therapy, it is pivotal that therapeutic genes potently and permanently inhibit viral replication. The anti-HIV genes should exhibit long-term efficacy without exerting adverse effects on lineage specific differentiation and cellular functions, and appropriate gene delivery vehicles with minimal toxicity are thus essential. There is growing evidence that the third generation lentiviral vector, which allows stable integration of the therapeutic gene, can be used safely [144-146]. Although the feasibility of HSC gene therapy has been demonstrated recently in a pilot clinical study [139], successful application of modified HSCs for HIV treatment requires further optimization, e.g., by improving the transduction efficiency and enhancing the engraftment of the modified cell population. Given the recent technological advances in the field, we believe that HSC modification forms an attractive means to develop a durable therapy for HIV infection. HSC gene therapy may also be combined with approaches that specifically target the HIV-1 reservoirs to achieve at least a "functional cure" (the virus is still present, but suppressed in the absence of antiretroviral drugs), since a "complete cure" (virus eradication from an infected individual) seems like an impossible mission at the moment.

\section{Acknowledgments}

This work was supported by the Nederlandse Organisatie voor Wetenschappelijk Onderzoek-Chemische Wetenschappen (NWO-CW, Top Grant) and Zorg Onderzoek Nederland-Medische Wetenschappen (ZonMw, Translational Gene Therapy Grant). 


\section{Conflicts of Interest}

The authors declare no conflict of interest.

\section{References}

1. UNAIDS. Reports on the Global AIDS Epidemic; UNAIDS: Geneva, Switzerland, 2013.

2. Gray, G.E.; Allen, M.; Moodie, Z.; Churchyard, G.; Bekker, L.G.; Nchabeleng, M.; Mlisana, K.; Metch, B.; De, B.G.; Latka, M.H.; et al. Safety and efficacy of the HVTN 503/Phambili study of a clade-B-based HIV-1 vaccine in South Africa: A double-blind, randomised, placebo-controlled test-of-concept phase 2b study. Lancet Infect. Dis. 2011, 11, 507-515. [CrossRef]

3. Hammer, S.M.; Sobieszczyk, M.E.; Janes, H.; Karuna, S.T.; Mulligan, M.J.; Grove, D.; Koblin, B.A.; Buchbinder, S.P.; Keefer, M.C.; Tomaras, G.D.; et al. Efficacy trial of a DNA/rAd5 HIV-1 preventive vaccine. N. Engl. J. Med. 2013, 369, 2083-2092. [CrossRef] [PubMed]

4. Kearney, M.F.; Spindler, J.; Shao, W.; Yu, S.; Anderson, E.M.; O’Shea, A.; Rehm, C.; Poethke, C.; Kovacs, N.; Mellors, J.W.; et al. Lack of detectable HIV-1 molecular evolution during suppressive antiretroviral therapy. PLoS Pathog. 2014, 10, e1004010. [CrossRef] [PubMed]

5. Katlama, C.; Deeks, S.G.; Autran, B.; Martinez-Picado, J.; van, L.J.; Rouzioux, C.; Miller, M.; Vella, S.; Schmitz, J.E.; Ahlers, J.; et al. Barriers to a cure for HIV: New ways to target and eradicate HIV-1 reservoirs. Lancet 2013, 381, 2109-2117. [CrossRef]

6. Llibre, J.M.; Buzon, M.J.; Massanella, M.; Esteve, A.; Dahl, V.; Puertas, M.C.; Domingo, P.; Gatell, J.M.; Larrouse, M.; Gutierrez, M.; et al. Treatment intensification with raltegravir in subjects with sustained HIV-1 viraemia suppression: A randomized 48-week study. Antivir. Ther. 2012, 17, 355-364. [CrossRef] [PubMed]

7. Perno, C.F.; Moyle, G.; Tsoukas, C.; Ratanasuwan, W.; Gatell, J.; Schechter, M. Overcoming resistance to existing therapies in HIV-infected patients: The role of new antiretroviral drugs. J. Med. Virol. 2008, 80, 565-576. [CrossRef] [PubMed]

8. Hutter, G.; Nowak, D.; Mossner, M.; Ganepola, S.; Mussig, A.; Allers, K.; Schneider, T.; Hofmann, J.; Kucherer, C.; Blau, O.; et al. Long-term control of HIV by CCR5 Delta32/Delta32 stem-cell transplantation. N. Engl. J. Med. 2009, 360, 692-698. [CrossRef] [PubMed]

9. Hutter, G.; Thiel, E. Allogeneic transplantation of CCR5-deficient progenitor cells in a patient with HIV infection: An update after 3 years and the search for patient No. 2. AIDS 2011, 25, 273-274. [CrossRef] [PubMed]

10. Baltimore, D. Gene therapy. Intracellular immunization. Nature 1988, 335, 395-396. [CrossRef] [PubMed]

11. Joseph, A.; Zheng, J.H.; Follenzi, A.; Dilorenzo, T.; Sango, K.; Hyman, J.; Chen, K.; Piechocka-Trocha, A.; Brander, C.; Hooijberg, E.; et al. Lentiviral vectors encoding human immunodeficiency virus type 1 (HIV-1)-specific T-cell receptor genes efficiently convert peripheral blood CD8 T lymphocytes into cytotoxic T lymphocytes with potent in vitro and in vivo HIV-1-specific inhibitory activity. J. Virol. 2008, 82, 3078-3089. [CrossRef] [PubMed]

12. Mitsuyasu, R.T.; Anton, P.A.; Deeks, S.G.; Scadden, D.T.; Connick, E.; Downs, M.T.; Bakker, A.; Roberts, M.R.; June, C.H.; Jalali, S.; et al. Prolonged survival and tissue trafficking following 
adoptive transfer of $\mathrm{CD} 4 \zeta$ gene-modified autologous $\mathrm{CD}^{+}$and $\mathrm{CD} 8^{+} \mathrm{T}$ cells in human immunodeficiency virus-infected subjects. Blood 2000, 96, 785-793. [PubMed]

13. Walker, R.E.; Bechtel, C.M.; Natarajan, V.; Baseler, M.; Hege, K.M.; Metcalf, J.A.; Stevens, R.; Hazen, A.; Blaese, R.M.; Chen, C.C.; et al. Long-term in vivo survival of receptor-modified syngeneic $\mathrm{T}$ cells in patients with human immunodeficiency virus infection. Blood 2000, 96, 467-474. [PubMed]

14. Deeks, S.G.; Wagner, B.; Anton, P.A.; Mitsuyasu, R.T.; Scadden, D.T.; Huang, C.; Macken, C.; Richman, D.D.; Christopherson, C.; June, C.H.; et al. A phase II randomized study of HIV-specific T-cell gene therapy in subjects with undetectable plasma viremia on combination antiretroviral therapy. Mol. Ther. 2002, 5, 788-797. [CrossRef] [PubMed]

15. Scholler, J.; Brady, T.L.; Binder-Scholl, G.; Hwang, W.T.; Plesa, G.; Hege, K.M.; Vogel, A.N.; Kalos, M.; Riley, J.L.; Deeks, S.G.; et al. Decade-long safety and function of retroviral-modified chimeric antigen receptor T cells. Sci. Transl. Med. 2012, 4. [CrossRef] [PubMed]

16. Levine, B.L.; Bernstein, W.B.; Aronson, N.E.; Schlienger, K.; Cotte, J.; Perfetto, S.; Humphries, M.J.; Ratto-Kim, S.; Birx, D.L.; Steffens, C.; et al. Adoptive transfer of costimulated CD4+ $\mathrm{T}$ cells induces expansion of peripheral $\mathrm{T}$ cells and decreased CCR5 expression in HIV infection. Nat. Med. 2002, 8, 47-53. [CrossRef] [PubMed]

17. Vatakis, D.N.; Arumugam, B.; Kim, S.G.; Bristol, G.; Yang, O.; Zack, J.A. Introduction of exogenous T-cell receptors into human hematopoietic progenitors results in exclusion of endogenous T-cell receptor expression. Mol. Ther. 2013, 21, 1055-1063. [CrossRef] [PubMed]

18. Malim, M.H.; Bohnlein, S.; Hauber, J.; Cullen, B.R. Functional dissection of the HIV-1 Rev trans-activator-derivation of a trans-dominant repressor of Rev function. Cell 1989, 58, 205-214. [CrossRef]

19. Malim, M.H.; Freimuth, W.W.; Liu, J.; Boyle, T.J.; Lyerly, H.K.; Cullen, B.R.; Nabel, G.J. Stable expression of transdominant Rev protein in human T cells inhibits human immunodeficiency virus replication. J. Exp. Med. 1992, 176, 1197-1201. [CrossRef] [PubMed]

20. Bahner, I.; Sumiyoshi, T.; Kagoda, M.; Swartout, R.; Peterson, D.; Pepper, K.; Dorey, F.; Reiser, J.; Kohn, D.B. Lentiviral vector transduction of a dominant-negative Rev gene into human CD34+ hematopoietic progenitor cells potently inhibits human immunodeficiency virus-1 replication. Mol. Ther. 2007, 15, 76-85. [CrossRef] [PubMed]

21. Morgan, R.A.; Walker, R.; Carter, C.S.; Natarajan, V.; Tavel, J.A.; Bechtel, C.; Herpin, B.; Muul, L.; Zheng, Z.; Jagannatha, S.; et al. Preferential survival of CD4+ T lymphocytes engineered with anti-human immunodeficiency virus (HIV) genes in HIV-infected individuals. Hum. Gene Ther. 2005, 16, 1065-1074. [CrossRef] [PubMed]

22. Ranga, U.; Woffendin, C.; Verma, S.; Xu, L.; June, C.H.; Bishop, D.K.; Nabel, G.J. Enhanced T cell engraftment after retroviral delivery of an antiviral gene in HIV-infected individuals. Proc. Natl. Acad. Sci. USA 1998, 95, 1201-1206. [CrossRef] [PubMed]

23. Apolloni, A.; Lin, M.H.; Sivakumaran, H.; Li, D.; Kershaw, M.H.; Harrich, D. A mutant Tat protein provides strong protection from HIV-1 infection in human CD4+ T cells. Hum. Gene Ther. 2013, 24, 270-282. [CrossRef] [PubMed] 
24. Porcellini, S.; Alberici, L.; Gubinelli, F.; Lupo, R.; Olgiati, C.; Rizzardi, G.P.; Bovolenta, C. The F12-Vif derivative Chim3 inhibits HIV-1 replication in CD4+ T lymphocytes and CD34+-derived macrophages by blocking HIV-1 DNA integration. Blood 2009, 113, 3443-3452. [CrossRef] [PubMed]

25. Walker, R.C., Jr.; Khan, M.A.; Kao, S.; Goila-Gaur, R.; Miyagi, E.; Strebel, K. Identification of dominant negative human immunodeficiency virus type 1 Vif mutants that interfere with the functional inactivation of APOBEC3G by virus-encoded Vif. J. Virol. 2010, 84, 5201-5211. [CrossRef] [PubMed]

26. Cara, A.; Rybak, S.M.; Newton, D.L.; Crowley, R.; Rottschafer, S.E.; Reitz, M.S., Jr.; Gusella, G.L. Inhibition of HIV-1 replication by combined expression of gag dominant negative mutant and a human ribonuclease in a tightly controlled HIV-1 inducible vector. Gene Ther. 1998, 5, 65-75. [CrossRef] [PubMed]

27. Trono, D.; Feinberg, M.B.; Baltimore, D. HIV-1 Gag mutants can dominantly interfere with the replication of the wild-type virus. Cell 1989, 59, 113-120. [CrossRef]

28. Cano, J.; Kalpana, G.V. Inhibition of early stages of HIV-1 assembly by INI1/hSNF5 transdominant negative mutant S6. J. Virol. 2011, 85, 2254-2265. [CrossRef] [PubMed]

29. Reddy, T.R.; Xu, W.; Mau, J.K.; Goodwin, C.D.; Suhasini, M.; Tang, H.; Frimpong, K.; Rose, D.W.; Wong-Staal, F. Inhibition of HIV replication by dominant negative mutants of Sam68, a functional homolog of HIV-1 Rev. Nat. Med. 1999, 5, 635-642. [CrossRef] [PubMed]

30. Marsh, K.; Soros, V.; Cochrane, A. Selective translational repression of HIV-1 RNA by Sam68DeltaC occurs by altering PABP1 binding to unspliced viral RNA. Retrovirology 2008, 5, 97. [CrossRef] [PubMed]

31. Sorin, M.; Cano, J.; Das, S.; Mathew, S.; Wu, X.; Davies, K.P.; Shi, X.; Cheng, S.W.; Ott, D.; Kalpana, G.V. Recruitment of a SAP18-HDAC1 complex into HIV-1 virions and its requirement for viral replication. PLoS Pathog. 2009, 5, e1000463. [CrossRef] [PubMed]

32. Daar, E.S.; Ho, D.D. Relative resistance of primary HIV-1 isolates to neutralization by soluble CD4. Am. J. Med. 1991, 90, 22S-26S. [CrossRef]

33. Falkenhagen, A.; Ameli, M.; Asad, S.; Read, S.E.; Joshi, S. A novel gene therapy strategy using secreted multifunctional anti-HIV proteins to confer protection to gene-modified and unmodified target cells. Gene Ther. 2014, 21, 175-187. [CrossRef] [PubMed]

34. Morgan, R.A.; Baler-Bitterlich, G.; Ragheb, J.A.; Wong-Staal, F.; Gallo, R.C.; Anderson, W.F. Further evaluation of soluble CD4 as an anti-HIV type 1 gene therapy: Demonstration of protection of primary human peripheral blood lymphocytes from infection by HIV type 1. AIDS Res. Hum. Retroviruses 1994, 10, 1507-1515. [CrossRef] [PubMed]

35. Egerer, L.; Volk, A.; Kahle, J.; Kimpel, J.; Brauer, F.; Hermann, F.G.; von, L.D. Secreted antiviral entry inhibitory (SAVE) peptides for gene therapy of HIV infection. Mol. Ther. 2011, 19, 1236-1244. [CrossRef] [PubMed]

36. Egelhofer, M.; Brandenburg, G.; Martinius, H.; Schult-Dietrich, P.; Melikyan, G.; Kunert, R.; Baum, C.; Choi, I.; Alexandrov, A.; von, L.D. Inhibition of human immunodeficiency virus type 1 entry in cells expressing gp41-derived peptides. J. Virol. 2004, 78, 568-575. [CrossRef] [PubMed] 
37. Perez, E.E.; Riley, J.L.; Carroll, R.G.; von, L.D.; June, C.H. Suppression of HIV-1 infection in primary CD4 $\mathrm{T}$ cells transduced with a self-inactivating lentiviral vector encoding a membrane expressed GP41-derived fusion inhibitor. Clin. Immunol. 2005, 115, 26-32. [CrossRef] [PubMed]

38. van Lunzen, J.; Glaunsinger, T.; Stahmer, I.; von Baehr, V.; Baum, C.; Schilz, A.; Kuehlcke, K.; Naundorf, S.; Martinius, H.; Hermann, F.; et al. Transfer of autologous gene-modified T cells in HIV-infected patients with advanced immunodeficiency and drug-resistant virus. Mol. Ther. 2007, 15, 1024-1033. [CrossRef] [PubMed]

39. Goncalves, J.; Silva, F.; Freitas-Vieira, A.; Santa-Marta, M.; Malho, R.; Yang, X.; Gabuzda, D.; Barbas, C., III. Functional neutralization of HIV-1 VIF protein by intracellular immunization inhibits reverse transcription and viral replication. J. Biol. Chem. 2002, 277, 32036-32045. [CrossRef] [PubMed]

40. Kitamura, Y.; Ishikawa, T.; Okui, N.; Kobayashi, N.; Kanda, T.; Shimada, T.; Miyake, K.; Yoshiike, K. Inhibition of replication of HIV-1 at both early and late stages of the viral life cycle by single-chain antibody against viral integrase. J. Acquir. Immune Defic. Syndr. Hum. Retrovirol. 1999, 20, 105-114. [CrossRef] [PubMed]

41. Levy-Mintz, P.; Duan, L.; Zhang, H.; Hu, B.; Dornadula, G.; Zhu, M.; Kulkosky, J.; Bizub-Bender, D.; Skalka, A.M.; Pomerantz, R.J. Intracellular expression of single-chain variable fragments to inhibit early stages of the viral life cycle by targeting human immunodeficiency virus type 1 integrase. J. Virol. 1996, 70, 8821-8832. [PubMed]

42. Mhashilkar, A.M.; Bagley, J.; Chen, S.Y.; Szilvay, A.M.; Helland, D.G.; Marasco, W.A. Inhibition of HIV-1 Tat-mediated LTR transactivation and HIV-1 infection by anti-Tat single chain intrabodies. EMBO J. 1995, 14, 1542-1551. [PubMed]

43. Shaheen, F.; Duan, L.; Zhu, M.; Bagasra, O.; Pomerantz, R.J. Targeting human immunodeficiency virus type 1 reverse transcriptase by intracellular expression of single-chain variable fragments to inhibit early stages of the viral life cycle. J. Virol. 1996, 70, 3392-3400. [PubMed]

44. Braun, S.E.; Taube, R.; Zhu, Q.; Wong, F.E.; Murakami, A.; Kamau, E.; Dwyer, M.; Qiu, G.; Daigle, J.; Carville, A.; et al. In vivo selection of $\mathrm{CD}^{+} \mathrm{T}$ cells transduced with a $\gamma$-retroviral vector expressing a single-chain intrabody targeting HIV-1 tat. Hum. Gene Ther. 2012, 23, 917-931. [CrossRef] [PubMed]

45. Schroers, R.; Davis, C.M.; Wagner, H.J.; Chen, S.Y. Lentiviral transduction of human T-lymphocytes with a RANTES intrakine inhibits human immunodeficiency virus type 1 infection. Gene Ther. 2002, 9, 889-897. [PubMed]

46. Simmons, G.; Reeves, J.D.; Hibbitts, S.; Stine, J.T.; Gray, P.W.; Proudfoot, A.E.; Clapham, P.R. Co-receptor use by HIV and inhibition of HIV infection by chemokine receptor ligands. Immunol. Rev. 2000, 177, 112-126. [CrossRef] [PubMed]

47. Yang, A.G.; Zhang, X.; Torti, F.; Chen, S.Y. Anti-HIV type 1 activity of wild-type and functional defective RANTES intrakine in primary human lymphocytes. Hum. Gene Ther. 1998, 9, 2005-2018. [CrossRef] [PubMed]

48. Didigu, C.A.; Wilen, C.B.; Wang, J.; Duong, J.; Secreto, A.J.; Danet-Desnoyers, G.A.; Riley, J.L.; Gregory, P.D.; June, C.H.; Holmes, M.C.; et al. Simultaneous zinc-finger nuclease editing of the 
HIV coreceptors CCR5 and CXCR4 protects CD4+ T cells from HIV-1 infection. Blood 2014, 123, 61-69. [CrossRef] [PubMed]

49. Perez, E.E.; Wang, J.; Miller, J.C.; Jouvenot, Y.; Kim, K.A.; Liu, O.; Wang, N.; Lee, G.; Bartsevich, V.V.; Lee, Y.L.; et al. Establishment of HIV-1 resistance in CD4+ T cells by genome editing using zinc-finger nucleases. Nat. Biotechnol. 2008, 26, 808-816. [CrossRef] [PubMed]

50. Wilen, C.B.; Wang, J.; Tilton, J.C.; Miller, J.C.; Kim, K.A.; Rebar, E.J.; Sherrill-Mix, S.A.; Patro, S.C.; Secreto, A.J.; Jordan, A.P.; et al. Engineering HIV-resistant human CD4+ T cells with CXCR4-specific zinc-finger nucleases. PLoS Pathog. 2011, 7, e1002020. [CrossRef] [PubMed]

51. Yuan, J.; Wang, J.; Crain, K.; Fearns, C.; Kim, K.A.; Hua, K.L.; Gregory, P.D.; Holmes, M.C.; Torbett, B.E. Zinc-finger nuclease editing of human CXCR4 promotes HIV-1 CD4 ${ }^{+} \mathrm{T}$ cell resistance and enrichment. Mol. Ther. 2012, 20, 849-859. [CrossRef] [PubMed]

52. Qu, X.; Wang, P.; Ding, D.; Li, L.; Wang, H.; Ma, L.; Zhou, X.; Liu, S.; Lin, S.; Wang, X.; et al. Zinc-finger-nucleases mediate specific and efficient excision of HIV-1 proviral DNA from infected and latently infected human T cells. Nucleic Acids Res. 2013, 41, 7771-7782. [CrossRef] [PubMed]

53. Badia, R.; Pauls, E.; Riveira-Munoz, E.; Clotet, B.; Este, J.A.; Ballana, E. Zinc-finger endonuclease targeting PSIP-1 inhibits HIV-1 integration. Antimicrob. Agents Chemother. 2014, 58, 4318-4327. [CrossRef] [PubMed]

54. Mussolino, C.; Morbitzer, R.; Lutge, F.; Dannemann, N.; Lahaye, T.; Cathomen, T. A novel TALE nuclease scaffold enables high genome editing activity in combination with low toxicity. Nucleic Acids Res. 2011, 39, 9283-9293. [CrossRef] [PubMed]

55. Holkers, M.; Maggio, I.; Liu, J.; Janssen, J.M.; Miselli, F.; Mussolino, C.; Recchia, A.; Cathomen, T.; Goncalves, M.A. Differential integrity of TALE nuclease genes following adenoviral and lentiviral vector gene transfer into human cells. Nucleic Acids Res. 2013, 41. [CrossRef] [PubMed]

56. Fadel, H.J.; Morrison, J.H.; Saenz, D.T.; Fuchs, J.R.; Kvaratskhelia, M.; Ekker, S.C.; Poeschla, E.M. TALEN knockout of the PSIP1 gene in human cells: Analyses of HIV-1 replication and allosteric integrase inhibitor mechanism. J. Virol. 2014, 88, 9704-9717. [CrossRef] [PubMed]

57. Chan, E.; Towers, G.J.; Qasim, W. Gene therapy strategies to exploit TRIM derived restriction factors against HIV-1. Viruses 2014, 6, 243-263. [CrossRef] [PubMed]

58. Neagu, M.R.; Ziegler, P.; Pertel, T.; Strambio-De-Castillia, C.; Grutter, C.; Martinetti, G.; Mazzucchelli, L.; Grutter, M.; Manz, M.G.; Luban, J. Potent inhibition of HIV-1 by TRIM5-cyclophilin fusion proteins engineered from human components. J. Clin. Invest. 2009, 119, 3035-3047. [CrossRef] [PubMed]

59. Saunders, K.O.; Wang, L.; Joyce, M.G.; Yang, Z.Y.; Balazs, A.B.; Cheng, C.; Ko, S.Y.; Kong, W.P.; Rudicell, R.S.; Georgiev, I.S.; et al. Broadly neutralizing human immunodeficiency virus type 1 antibody gene transfer protects non-human primates from mucosal simian-human immunodeficiency virus infection. J. Virol. 2015. [CrossRef] [PubMed]

60. Gardner, M.R.; Kattenhorn, L.M.; Kondur, H.R.; von, S.M.; Dorfman, T.; Chiang, J.J.; Haworth, K.G.; Decker, J.M.; Alpert, M.D.; Bailey, C.C.; et al. AAV-expressed eCD4-Ig provides 
durable protection from multiple SHIV challenges. Nature 2015, 519, 87-91. [CrossRef] [PubMed]

61. Berkhout, B.; Sanders, R.W. Gene therapy as a vaccine for HIV-1. Expert Opin. Biol. Ther. 2012, 12, 1315-1321. [CrossRef] [PubMed]

62. Balazs, A.B.; Chen, J.; Hong, C.M.; Rao, D.S.; Yang, L.; Baltimore, D. Antibody-based protection against HIV infection by vectored immunoprophylaxis. Nature 2012, 481, 81-84. [CrossRef] [PubMed]

63. Balazs, A.B.; Ouyang, Y.; Hong, C.M.; Chen, J.; Nguyen, S.M.; Rao, D.S.; An, D.S.; Baltimore, D. Vectored immunoprophylaxis protects humanized mice from mucosal HIV transmission. Nat. Med. 2014, 20, 296-300. [CrossRef] [PubMed]

64. Humeau, L.M.; Binder, G.K.; Lu, X.; Slepushkin, V.; Merling, R.; Echeagaray, P.; Pereira, M.; Slepushkina, T.; Barnett, S.; Dropulic, L.K.; et al. Efficient lentiviral vector-mediated control of HIV-1 replication in CD4 lymphocytes from diverse HIV+ infected patients grouped according to CD4 count and viral load. Mol. Ther. 2004, 9, 902-913. [CrossRef] [PubMed]

65. Lu, X.; Yu, Q.; Binder, G.K.; Chen, Z.; Slepushkina, T.; Rossi, J.; Dropulic, B. Antisense-mediated inhibition of human immunodeficiency virus (HIV) replication by use of an HIV type 1-based vector results in severely attenuated mutants incapable of developing resistance. J. Virol. 2004, 78, 7079-7088. [CrossRef] [PubMed]

66. Vickers, T.; Baker, B.F.; Cook, P.D.; Zounes, M.; Buckheit, R.W., Jr.; Germany, J.; Ecker, D.J. Inhibition of HIV-LTR gene expression by oligonucleotides targeted to the TAR element. Nucleic Acids Res. 1991, 19, 3359-3368. [CrossRef] [PubMed]

67. Amado, R.G.; Mitsuyasu, R.T.; Rosenblatt, J.D.; Ngok, F.K.; Bakker, A.; Cole, S.; Chorn, N.; Lin, L.S.; Bristol, G.; Boyd, M.P.; et al. Anti-human immunodeficiency virus hematopoietic progenitor cell-delivered ribozyme in a phase I study: Myeloid and lymphoid reconstitution in human immunodeficiency virus type-1-infected patients. Hum. Gene Ther. 2004, 15, 251-262. [CrossRef] [PubMed]

68. MacPherson, J.L.; Boyd, M.P.; Arndt, A.J.; Todd, A.V.; Fanning, G.C.; Ely, J.A.; Elliott, F.; Knop, A.; Raponi, M.; Murray, J.; et al. Long-term survival and concomitant gene expression of ribozyme-transduced CD4+ T-lymphocytes in HIV-infected patients. J. Gene Med. 2005, 7, 552-564. [CrossRef] [PubMed]

69. Mitsuyasu, R.T.; Merigan, T.C.; Carr, A.; Zack, J.A.; Winters, M.A.; Workman, C.; Bloch, M.; Lalezari, J.; Becker, S.; Thornton, L.; et al. Phase 2 gene therapy trial of an anti-HIV ribozyme in autologous CD34+ cells. Nat. Med. 2009, 15, 285-292. [CrossRef] [PubMed]

70. Michienzi, A.; Castanotto, D.; Lee, N.; Li, S.; Zaia, J.A.; Rossi, J.J. RNA-mediated inhibition of HIV in a gene therapy setting. Ann. N. Y. Acad. Sci. 2003, 1002, 63-71. [CrossRef] [PubMed]

71. Wong-Staal, F.; Poeschla, E.M.; Looney, D.J. A controlled, Phase 1 clinical trial to evaluate the safety and effects in HIV-1 infected humans of autologous lymphocytes transduced with a ribozyme that cleaves HIV-1 RNA. Hum. Gene Ther. 1998, 9, 2407-2425. [CrossRef] [PubMed]

72. Hotchkiss, G.; Maijgren-Steffensson, C.; Ahrlund-Richter, L. Efficacy and mode of action of hammerhead and hairpin ribozymes against various HIV-1 target sites. Mol. Ther. 2004, 10, 172-180. [CrossRef] [PubMed] 
73. Yamada, O.; Kraus, G.; Luznik, L.; Yu, M.; Wong-Staal, F. A chimeric human immunodeficiency virus type 1 (HIV-1) minimal Rev response element-ribozyme molecule exhibits dual antiviral function and inhibits cell-cell transmission of HIV-1. J. Virol. 1996, 70, 1596-1601. [PubMed]

74. Sullenger, B.A.; Gallardo, H.F.; Ungers, G.E.; Gilboa, E. Analysis of trans-acting response decoy RNA-mediated inhibition of human immunodeficiency virus type 1 transactivation. J. Virol. 1991, 65, 6811-6816. [PubMed]

75. Sullenger, B.A.; Gallardo, H.F.; Ungers, G.E.; Gilboa, E. Overexpression of TAR sequences renders cells resistant to human immunodeficiency virus replication. Cell 1990, 63, 601-608. [CrossRef]

76. Lee, T.C.; Sullenger, B.A.; Gallardo, H.F.; Ungers, G.E.; Gilboa, E. Overexpression of RRE-derived sequences inhibits HIV-1 replication in CEM cells. New Biol. 1992, 4, 66-74. [PubMed]

77. Michienzi, A.; Li, S.; Zaia, J.A.; Rossi, J.J. A nucleolar TAR decoy inhibitor of HIV-1 replication. Proc. Natl. Acad. Sci. USA 2002, 99, 14047-14052. [CrossRef] [PubMed]

78. Bai, J.; Banda, N.; Lee, N.S.; Rossi, J.; Akkina, R. RNA-based anti-HIV-1 gene therapeutic constructs in SCID-hu mouse model. Mol. Ther. 2002, 6, 770-782. [CrossRef] [PubMed]

79. Banerjea, A.; Li, M.J.; Remling, L.; Rossi, J.; Akkina, R. Lentiviral transduction of Tar Decoy and CCR5 ribozyme into CD34+ progenitor cells and derivation of HIV-1 resistant $\mathrm{T}$ cells and macrophages. AIDS Res. Ther. 2004, 1. [CrossRef] [PubMed]

80. Kohn, D.B.; Bauer, G.; Rice, C.R.; Rothschild, J.C.; Carbonaro, D.A.; Valdez, P.; Hao, Q.; Zhou, C.; Bahner, I.; Kearns, K.; et al. A clinical trial of retroviral-mediated transfer of a rev-responsive element decoy gene into $\mathrm{CD}_{3}{ }^{+}$cells from the bone marrow of human immunodeficiency virus-1-infected children. Blood 1999, 94, 368-371. [PubMed]

81. Chendrimada, T.P.; Gregory, R.I.; Kumaraswamy, E.; Norman, J.; Cooch, N.; Nishikura, K.; Shiekhattar, R. TRBP recruits the Dicer complex to Ago2 for microRNA processing and gene silencing. Nature 2005, 436, 740-744. [CrossRef] [PubMed]

82. Elbashir, S.M.; Harborth, J.; Lendeckel, W.; Yalcin, A.; Weber, K.; Tuschl, T. Duplexes of 21-nucleotide RNAs mediate RNA interference in cultured mammalian cells. Nature 2001, 411, 494-498. [CrossRef] [PubMed]

83. Anderson, J.; Banerjea, A.; Akkina, R. Bispecific short hairpin siRNA constructs targeted to CD4, CXCR4, and CCR5 confer HIV-1 resistance. Oligonucleotides 2003, 13, 303-312. [CrossRef] [PubMed]

84. Chang, L.J.; Liu, X.; He, J. Lentiviral siRNAs targeting multiple highly conserved RNA sequences of human immunodeficiency virus type 1. Gene Ther. 2005, 12, 1133-1144. [CrossRef] [PubMed]

85. Eekels, J.J.; Geerts, D.; Jeeninga, R.E.; Berkhout, B. Long-term inhibition of HIV-1 replication with RNA interference against cellular co-factors. Antiviral Res. 2011, 89, 43-53. [CrossRef] [PubMed]

86. Surabhi, R.M.; Gaynor, R.B. RNA interference directed against viral and cellular targets inhibits human immunodeficiency virus type 1 replication. J. Virol. 2002, 76, 12963-12973. [CrossRef] [PubMed] 
87. Von Eije, K.J.; Ter Brake, O.; Berkhout, B. Stringent testing identifies highly potent and escape-proof anti-HIV short hairpin RNAs. J. Gene Med. 2009, 11, 459-467. [CrossRef] [PubMed]

88. Westerhout, E.M.; Vink, M.; Haasnoot, P.C.; Das, A.T.; Berkhout, B. A conditionally replicating HIV-based vector that stably expresses an antiviral shRNA against HIV-1 replication. Mol. Ther. 2006, 14, 268-275. [CrossRef] [PubMed]

89. Shimizu, S.; Kamata, M.; Kittipongdaja, P.; Chen, K.N.; Kim, S.; Pang, S.; Boyer, J.; Qin, F.X.; An, D.S.; Chen, I.S. Characterization of a potent non-cytotoxic shRNA directed to the HIV-1 co-receptor CCR5. Genet. Vaccines Ther. 2009, 7, 8. [CrossRef] [PubMed]

90. Ter Brake, O.; Konstantinova, P.; Ceylan, M.; Berkhout, B. Silencing of HIV-1 with RNA interference: A multiple shRNA approach. Mol. Ther. 2006, 14, 883-892. [CrossRef] [PubMed]

91. Hammond, S.M.; Bernstein, E.; Beach, D.; Hannon, G.J. An RNA-directed nuclease mediates post-transcriptional gene silencing in Drosophila cells. Nature 2000, 404, 293-296. [PubMed]

92. Berkhout, B.; Liu, Y.P. Towards improved shRNA and miRNA reagents as inhibitors of HIV-1 replication. Future Microbiol. 2014, 9, 561-571. [CrossRef] [PubMed]

93. Liu, Y.P.; Schopman, N.C.; Berkhout, B. Dicer-independent processing of short hairpin RNAs. Nucleic Acids Res. 2013, 41, 3723-3733. [CrossRef] [PubMed]

94. Liu, Y.P.; Karg, M.; Harwig, A.; Herrera-Carrillo, E.; Jongejan, A.; van kampen, A.; Berkhout, B. Mechanistic insights on the dicer-independent Ago2-mediated processing of AgoshRNAs. RNA Biol. 2014, 12, 92-100. [CrossRef] [PubMed]

95. Coley, W.; Van, D.R.; Carpio, L.; Guendel, I.; Kehn-Hall, K.; Chevalier, S.; Narayanan, A.; Luu, T.; Lee, N.; Klase, Z.; et al. Absence of DICER in monocytes and its regulation by HIV-1. J. Biol. Chem. 2010, 285, 31930-31943. [CrossRef] [PubMed]

96. Harwig, A.; Herrera-Carrillo, E.; Jongejan, A.; van kampen, A.; Berkhout, B. Deep sequence analysis of AgoshRNA processing reveals $3^{\prime} \mathrm{A}$ addition and trimming. Mol. Ther. Nucleic Acids 2015, 4. in press. [CrossRef]

97. Gu, S.; Jin, L.; Zhang, Y.; Huang, Y.; Zhang, F.; Valdmanis, P.N.; Kay, M.A. The loop position of shRNAs and pre-miRNAs is critical for the accuracy of Dicer processing in vivo. Cell 2012, 151, 900-911. [CrossRef] [PubMed]

98. Dueck, A.; Ziegler, C.; Eichner, A.; Berezikov, E.; Meister, G. MicroRNAs associated with the different human Argonaute proteins. Nucleic Acids Res. 2012, 40, 9850-9862. [CrossRef] [PubMed]

99. Herrera-Carrillo, E.; Harwig, A.; Liu, Y.P.; Berkhout, B. Probing the shRNA characteristics that hinder Dicer recognition and consequently allow Ago-mediated processing and AgoshRNA activity. RNA 2014, 20, 1410-1418. [CrossRef] [PubMed]

100. Herrera-Carrillo, E.; Harwig, A.; Berkhout, B. Towards optimization of AgoshRNA molecules that use a non-canonical RNAi pathway: Variations in the top and bottom base pairs. RNA Biol. 2015, 12, 447-456. [CrossRef] [PubMed]

101. Anderson, J.; Akkina, R. Human immunodeficiency virus type 1 restriction by human-rhesus chimeric tripartite motif $5 \alpha$ (TRIM $5 \alpha$ ) in $\mathrm{CD}_{3} 4^{+}$cell-derived macrophages in vitro and in $\mathrm{T}$ 
cells in vivo in severe combined immunodeficient (SCID-hu) mice transplanted with human fetal tissue. Hum. Gene Ther. 2008, 19, 217-228. [CrossRef] [PubMed]

102. DiGiusto, D.L.; Krishnan, A.; Li, L.; Li, H.; Li, S.; Rao, A.; Mi, S.; Yam, P.; Stinson, S.; Kalos, M.; et al. RNA-based gene therapy for HIV with lentiviral vector-modified $\mathrm{CD} 4^{+}{ }^{+}$cells in patients undergoing transplantation for AIDS-related lymphoma. Sci. Transl. Med. 2010, 2 , 36-43. [CrossRef] [PubMed]

103. Ter Brake, O.; 't Hooft, K.; Liu, Y.P.; Centlivre, M.; von Eije, K.J.; Berkhout, B. Lentiviral vector design for multiple shRNA expression and durable HIV-1 inhibition. Mol. Ther. 2008, 16, 557-564. [CrossRef] [PubMed]

104. Liu, Y.P.; Haasnoot, J.; Ter Brake, O.; Berkhout, B.; Konstantinova, P. Inhibition of HIV-1 by multiple siRNAs expressed from a single microRNA polycistron. Nucleic Acids Res. 2008, 36, 2811-2824. [CrossRef] [PubMed]

105. Snyder, L.L.; Ahmed, I.; Steel, L.F. RNA polymerase III can drive polycistronic expression of functional interfering RNAs designed to resemble microRNAs. Nucleic Acids Res. 2009, 37. [CrossRef] [PubMed]

106. Choi, J.G.; Bharaj, P.; Abraham, S.; Ma, H.; Yi, G.; Ye, C.; Dang, Y.; Manjunath, N.; Wu, H.; Shankar, P. Multiplexing seven miRNA-based shRNAs to suppress HIV replication. Mol. Ther. 2015, 23, 310-320. [CrossRef] [PubMed]

107. Liu, Y.P.; von Eije, K.J.; Schopman, N.C.; Westerink, J.T.; Ter Brake, O.; Haasnoot, J.; Berkhout, B. Combinatorial RNAi against HIV-1 using extended short hairpin RNAs. Mol. Ther. 2009, 17, 1712-1723. [CrossRef] [PubMed]

108. Liu, Y.P.; Haasnoot, J.; Berkhout, B. Design of extended short hairpin RNAs for HIV-1 inhibition. Nucleic Acids Res. 2007, 35, 5683-5693. [CrossRef] [PubMed]

109. Konstantinova, P.; de Vries, W.; Haasnoot, J.; Ter Brake, O.; de Haan, P.; Berkhout, B. Inhibition of human immunodeficiency virus type 1 by RNA interference using long-hairpin RNA. Gene Ther. 2006, 13, 1403-1413. [CrossRef] [PubMed]

110. Saayman, S.; Arbuthnot, P.; Weinberg, M.S. Deriving four functional anti-HIV siRNAs from a single Pol III-generated transcript comprising two adjacent long hairpin RNA precursors. Nucleic Acids Res. 2010, 38, 6652-6663. [CrossRef] [PubMed]

111. Liu, Y.P.; Berkhout, B. Combinatorial RNAi strategies against HIV-1 and other escape-prone viruses. Int. J. BioSci. Technol. 2008, 1, 1-10.

112. Boutimah, F.; Eekels, J.J.; Liu, Y.P.; Berkhout, B. Antiviral strategies combining antiretroviral drugs with RNAi-mediated attack on HIV-1 and cellular co-factors. Antiviral Res. 2013, 98, 121-129. [CrossRef] [PubMed]

113. Schopman, N.C.; Braun, A.; Berkhout, B. Directed HIV-1 evolution of protease inhibitor resistance by second-generation short hairpin RNAs. Antimicrob. Agents Chemother. 2012, 56, 479-486. [CrossRef] [PubMed]

114. Anderson, J.; Li, M.J.; Palmer, B.; Remling, L.; Li, S.; Yam, P.; Yee, J.K.; Rossi, J.; Zaia, J.; Akkina, R. Safety and efficacy of a lentiviral vector containing three anti-HIV genes-CCR5 ribozyme, Tat-Rev siRNA, and TAR decoy-In SCID-hu mouse-derived T cells. Mol. Ther. 2007, 15, 1182-1188. [CrossRef] [PubMed] 
115. Walker, J.E.; Chen, R.X.; McGee, J.; Nacey, C.; Pollard, R.B.; Abedi, M.; Bauer, G.; Nolta, J.A.; Anderson, J.S. Generation of an HIV-1-resistant immune system with CD34 ${ }^{+}$hematopoietic stem cells transduced with a triple-combination anti-HIV lentiviral vector. J. Virol. 2012, 86, 5719-5729. [CrossRef] [PubMed]

116. Kiem, H.P.; Wu, R.A.; Sun, G.; von, L.D.; Rossi, J.J.; Trobridge, G.D. Foamy combinatorial anti-HIV vectors with MGMTP140K potently inhibit HIV-1 and SHIV replication and mediate selection in vivo. Gene Ther. 2010, 17, 37-49. [CrossRef] [PubMed]

117. Neff, C.P.; Zhou, J.; Remling, L.; Kuruvilla, J.; Zhang, J.; Li, H.; Smith, D.D.; Swiderski, P.; Rossi, J.J.; Akkina, R. An aptamer-siRNA chimera suppresses HIV-1 viral loads and protects from helper $\mathrm{CD}^{+} \mathrm{T}$ cell decline in humanized mice. Sci. Transl. Med. 2011, 3. [CrossRef] [PubMed]

118. Zhou, J.; Rossi, J.J. Current progress in the development of RNAi-based therapeutics for HIV-1. Gene Ther. 2011, 18, 1134-1138. [CrossRef] [PubMed]

119. Mitchell, R.S.; Beitzel, B.F.; Schroder, A.R.; Shinn, P.; Chen, H.; Berry, C.C.; Ecker, J.R.; Bushman, F.D. Retroviral DNA integration: ASLV, HIV, and MLV show distinct target site preferences. PLoS. Biol. 2004, 2, e234. [CrossRef] [PubMed]

120. Hacein-Bey-Abina, S.; Garrigue, A.; Wang, G.P.; Soulier, J.; Lim, A.; Morillon, E.; Clappier, E.; Caccavelli, L.; Delabesse, E.; Beldjord, K.; et al. Insertional oncogenesis in 4 patients after retrovirus-mediated gene therapy of SCID-X1. J. Clin. Invest. 2008, 118, 3132-3142. [CrossRef] [PubMed]

121. Wu, X.; Li, Y.; Crise, B.; Burgess, S.M. Transcription start regions in the human genome are favored targets for MLV integration. Science 2003, 300, 1749-1751. [CrossRef] [PubMed]

122. Maldarelli, F.; Wu, X.; Su, L.; Simonetti, F.R.; Shao, W.; Hill, S.; Spindler, J.; Ferris, A.L.; Mellors, J.W.; Kearney, M.F.; et al. HIV latency. Specific HIV integration sites are linked to clonal expansion and persistence of infected cells. Science 2014, 345, 179-183. [CrossRef] [PubMed]

123. Wagner, T.A.; McLaughlin, S.; Garg, K.; Cheung, C.Y.; Larsen, B.B.; Styrchak, S.; Huang, H.C.; Edlefsen, P.T.; Mullins, J.I.; Frenkel, L.M. HIV latency. Proliferation of cells with HIV integrated into cancer genes contributes to persistent infection. Science 2014, 345, 570-573. [CrossRef] [PubMed]

124. Akkina, R.K.; Walton, R.M.; Chen, M.L.; Li, Q.X.; Planelles, V.; Chen, I.S. High-efficiency gene transfer into CD34+ cells with a human immunodeficiency virus type 1-based retroviral vector pseudotyped with vesicular stomatitis virus envelope glycoprotein, G. J. Virol. 1996, 70, 2581-2585. [PubMed]

125. Trono, D. HIV accessory proteins: Leading roles for the supporting cast. Cell 1995, 82, 189-192. [CrossRef]

126. Miyoshi, H.; Blomer, U.; Takahashi, M.; Gage, F.H.; Verma, I.M. Development of a self-inactivating lentivirus vector. J. Virol. 1998, 72, 8150-8157. [PubMed]

127. Zufferey, R.; Dull, T.; Mandel, R.J.; Bukovsky, A.; Quiroz, D.; Naldini, L.; Trono, D. Self-inactivating lentivirus vector for safe and efficient in vivo gene delivery. J. Virol. 1998, 72, 9873-9880. [PubMed] 
128. Bukovsky, A.A.; Song, J.P.; Naldini, L. Interaction of human immunodeficiency virus-derived vectors with wild-type virus in transduced cells. J. Virol. 1999, 73, 7087-7092. [PubMed]

129. Liu, Y.P.; Berkhout, B. Lentiviral delivery of RNAi effectors against HIV-1. Curr. Top. Med. Chem. 2009, 9, 1130-1143. [CrossRef] [PubMed]

130. Liu, Y.P.; Vink, M.A.; Westerink, J.T.; Ramirez de, A.E.; Konstantinova, P.; Ter Brake, O.; Berkhout, B. Titers of lentiviral vectors encoding shRNAs and miRNAs are reduced by different mechanisms that require distinct repair strategies. RNA 2010, 16, 1328-1339. [CrossRef] [PubMed]

131. Ter Brake, O.; Berkhout, B. Lentiviral vectors that carry anti-HIV shRNAs: Problems and solutions. J. Gene Med. 2007, 9, 743-750. [CrossRef] [PubMed]

132. Ter Brake, O.; von Eije, K.J.; Berkhout, B. Probing the sequence space available for HIV-1 evolution. AIDS 2008, 22, 1875-1877. [CrossRef] [PubMed]

133. Von Eije, K.J.; Ter Brake, O.; Berkhout, B. Human immunodeficiency virus type 1 escape is restricted when conserved genome sequences are targeted by RNA interference. J. Virol. 2008, 82, 2895-2903. [CrossRef] [PubMed]

134. Eekels, J.J.; Pasternak, A.O.; Schut, A.M.; Geerts, D.; Jeeninga, R.E.; Berkhout, B. A competitive cell growth assay for the detection of subtle effects of gene transduction on cell proliferation. Gene Ther. 2012, 19, 1058-1064. [CrossRef] [PubMed]

135. Centlivre, M.; Legrand, N.; Klamer, S.; Liu, Y.P.; Eije, K.J.; Bohne, M.; Rijnstra, E.S.; Weijer, K.; Blom, B.; Voermans, C.; et al. Preclinical in vivo evaluation of the safety of a multi-shRNA-based gene therapy against HIV-1. Mol. Ther. Nucleic Acids 2013, 2. [CrossRef] [PubMed]

136. Holt, N.; Wang, J.; Kim, K.; Friedman, G.; Wang, X.; Taupin, V.; Crooks, G.M.; Kohn, D.B.; Gregory, P.D.; Holmes, M.C.; et al. Zinc finger nuclease-mediated CCR5 knockout hematopoietic stem cell transplantation controls HIV-1 in vivo. Nat. Biotechnol. 2010, 28, 839-847. [CrossRef] [PubMed]

137. Herrera-Carrillo, E.; Liu, Y.P.; Berkhout, B. The impact of unprotected T cells in RNAi-based gene therapy for HIV-AIDS. Mol. Ther. 2014, 22, 596-606. [CrossRef] [PubMed]

138. Herrera-Carrillo, E.; Berkhout, B. The impact of HIV-1 genetic diversity on the efficacy of a combinatorial RNAi-based gene therapy. Gene Ther. 2015. [CrossRef] [PubMed]

139. Tebas, P.; Stein, D.; Binder-Scholl, G.; Mukherjee, R.; Brady, T.; Rebello, T.; Humeau, L.; Kalos, M.; Papasavvas, E.; Montaner, L.J.; et al. Antiviral effects of autologous CD4 T cells genetically modified with a conditionally replicating lentiviral vector expressing long antisense to HIV. Blood 2013, 121, 1524-1533. [CrossRef] [PubMed]

140. Daw, S.; Wynn, R.; Wallace, H. Management of relapsed and refractory classical Hodgkin lymphoma in children and adolescents. Br. J. Haematol. 2011, 152, 249-260. [CrossRef] [PubMed]

141. Johnston, L.J.; Horning, S.J. Autologous hematopoietic cell transplantation in Hodgkin's disease. Biol. Blood Marrow Transpl. 2000, 6, 289-300. [CrossRef]

142. Kang, E.M.; De, W.M.; Malech, H.; Morgan, R.A.; Carter, C.; Leitman, S.F.; Childs, R.; Barrett, A.J.; Little, R.; Tisdale, J.F. Gene therapy-based treatment for HIV-positive patients with malignancies. J. Hematother. Stem. Cell Res. 2002, 11, 809-816. [CrossRef] [PubMed] 
143. Savkovic, B.; MacPherson, J.L.; Zaunders, J.; Kelleher, A.D.; Knop, A.E.; Pond, S.; Evans, L.; Symonds, G.; Murray, J.M. T-lymphocyte perturbation following large-scale apheresis and hematopoietic stem cell transplantation in HIV-infected individuals. Clin. Immunol. 2012, 144, 159-171. [CrossRef] [PubMed]

144. Biffi, A.; Montini, E.; Lorioli, L.; Cesani, M.; Fumagalli, F.; Plati, T.; Baldoli, C.; Martino, S.; Calabria, A.; Canale, S.; et al. Lentiviral hematopoietic stem cell gene therapy benefits metachromatic leukodystrophy. Science 2013, 341. [CrossRef] [PubMed]

145. Aiuti, A.; Biasco, L.; Scaramuzza, S.; Ferrua, F.; Cicalese, M.P.; Baricordi, C.; Dionisio, F.; Calabria, A.; Giannelli, S.; Castiello, M.C.; et al. Lentiviral hematopoietic stem cell gene therapy in patients with Wiskott-Aldrich syndrome. Science 2013, 341. [CrossRef] [PubMed]

146. Cartier, N.; Hacein-Bey-Abina, S.; Bartholomae, C.C.; Veres, G.; Schmidt, M.; Kutschera, I.; Vidaud, M.; Abel, U.; Dal-Cortivo, L.; Caccavelli, L.; et al. Hematopoietic stem cell gene therapy with a lentiviral vector in X-linked adrenoleukodystrophy. Science 2009, 326, 818-823. [CrossRef] [PubMed]

(C) 2015 by the authors; licensee MDPI, Basel, Switzerland. This article is an open access article distributed under the terms and conditions of the Creative Commons Attribution license (http://creativecommons.org/licenses/by/4.0/). 